\title{
ANALISIS HUKUM PEMIDANAAN PELAKU TINDAK PIDANA PEMALSUAN MEREK (STUDI KASUS PUTUSAN NO: 87/PID.SUS/2019/PN.PTI )
}

\author{
Erfandi Sinurat, Juli Esther, Ojak Nainggolan \\ Fakultas Hukum, Universitas HKBP Nommensen \\ julyesther@uhn.ac.id
}

\begin{abstract}
Abstrak
Merek merupakan tanda pembeda dari produk sejenis yang berasal dari produsen lain. Kenyataan yang ada di masyarakat, memang saat ini banyak dijumpai di pasar berbagai macam produk yang dipalsukan adapun dengan membonceng merek (passing off). Penelitian ini menggunakan metode penilitian hukum normatif dengan pendektan studi kasus. Dengan menggunakan dua pendekatan masalah, yakni pendekatan perundangundangan dan pendekatan konsep teori hukum. Dengan mengolah bahan hukum primer dan sekunder secara kualitatif. Sehingga dari hasil penelitian ini diketahui tindak pidana pemalsuan merek dapat dimintakan pertanggungjawabannya sesuai ketentuan perundangundangan mampu bertanggungjawab, atau dapat dikatakan bahwa orang tersebut jiwanya normal dan sehat tanpa adanya kekurangan dalam bertanggungjawab. Dalam pertimbangan hakim terhadap kasus merek didasarkan pada penilaian objektif dari hakim yang memeriksa dan mengadili perkaradasar pertimbangan hakim terdiri dari dasar pertimbangan yuridis dan non yuridis. Dalam studi kasus yang diteliti dari putusan No: 87/Pid.Sus/2019/PN.Pti. Penegak hukum di harapkan mampu memberantas dan mengatasi permasalahan tindak pidana pemalsuan merek, maka dari itu hakim harus memberikan hukuman yang maksimal agar dapat memberikan efek jera.
\end{abstract}

\section{Kata Kunci : Merek, Produk, Pemidanaan Pelaku Tindak Pidana Pemalsuan Merek, Efek Jera}

\begin{abstract}
Brands are a distinguishing sign of similar products coming from other manufacturers. The reality that exists in the community, indeed today is found in the market of various kinds of products that are counterfeited as for by branding (passing off). This study uses normative legal methods with case study shorts. By using two approaches to the problem, namely the statutory approach and the concept approach of legal theory. By processing primary and secondary legal materials qualitatively. So that from the results of this study known the criminal act of brand counterfeiting can be held accountable in accordance with the provisions of legislation able to be responsible, or it can be said that the person's soul is normal and healthy without any deficiency in being responsible. In consideration of the judge's case the brand is based on the objective judgment of the judge who examines and adjudicates the basic case of the judge's consideration consisting of the basis of juridical and non juridical considerations. In the case study examined from verdict No: 87/Pid.Sus/2019/PN. Pti Penegak hukum is expected to eradicate and solve the problem of brand counterfeiting crimes, therefore the judge must give the maximum penalty in order to provide deterrent effect.
\end{abstract}

Keywords: Brands, Products, Deliberately Abuse Their Residence Permit, Deterrent Effect 


\section{PATIK : JURNAL HUKUM Vol : 09 No. 2, Agustus 2020, Hal 70 - 78}

\section{Pendahuluan}

Seiring pesatnya persaingan perdagangan barang dan jasa maka tidak heran, merek memiliki peranan yang sangat penting. Merek adalah tanda yang ditampilkan secara grafis berupa gambar, logo, nama, kata, huruf, angka, susunan dan warna yang digunakan dalam perdagangan barang dan jasa. Merek merupakan ujung tombak perdagangan barang dan jasa. Khususnya mengenai kualitas produk tidak dapat dibayangkan apabila suatu produk tidak memiliki merek, tentu produk yang bersangkutan tidak akan dikenal oleh konsumen.

Setiap perdagangan barang dan jasa akan memiliki merek yang digunakan untuk membuat produk barang yang mereka hasilkan. Oleh karena itu, merek mempunyai nilai atau ekuitas yang akan menjadi tolak ukur suatu produk yang dalam perdagangan.Hal ini dapat dimengerti karena hal pertama yang dilihat sebelum membeli sebuah produk adalah merek dari produk itu sendiri karena merek memiliki peranan penting dalam dunia perdagangan dan dalam melindungi reputasi yang dibangun oleh banyak perusahaan .

Melalui merek, pengusaha dapat menjaga dan memberikan jaminan akan kualitas (a guarantee of quality) ${ }^{1}$ barang dan/atau jasa yang dihasilkan dan mencegah tindakan persaingan (konkurensi) yang tidak jujur dari pengusaha lain yang beritikad buruk yang bermaksud membonceng reputasinya (passing off) oleh karena itu merek mempunyai nilai atau ekuitas. Barang-barang yang memiliki merek terkenal dan dikenal secara luas bagi produsen seperti : Bonia, Rolex, G.Shock, DLLbarang ini menjadi diminati bagi orang yang mempunyai penghasilan tinggi bahkan juga di kalangan remaja.

Salah satu ciri utama dari merek terkenal adalah bahwa reputasi merek tidak harus terbatas pada produk tertentu atau jenis produk. Manusia yang memiliki sifat yang sering dihadapkan kepada suatu kebutuhan pemuas diri selalu tidak pernah cukup dan bahkan keinginan untuk mempertahankan status diri salah satu nya dengan membeli barang yang terkenal tanpa melihat dengan teliti barang yang akan dibelinya. Menjadi salah satu jalan pintas bagi pelaku usaha yang ingin mendapatkan keuntungan yang lebih besar tanpa harus membayar pajak serta melumpuhkan para kompetitornya di dunia perdagangan. Memanfaatkan merek tersebut dengan menyerupai bentuk dari pada barang tersebut dan menempel merek yang tampak kelihatan dengan aslinya.

Pemalsuan merek ini akan merugikan berbagai pihak, baik konsumen maupun pemilik merek asli dari merek itu sendiri. Perbuatan pemalsuan merek baik secara keseluruhan maupun sebagian, ini dilakukan agar didalam usahanya untuk mendapatkan keuntungan yang sebesar-besarnya. Perbuatan ini dilakukan untuk mendapatkan peningkatan dalam usaha dengan cepat. Pengertian Merek pada Pasal 1 ayat 1 UndangUndang Nomor 20 Tahun 2016 Tentang Merek dan Indikasi Geografis, lebih detail menguraikan pengertian tentang merek, diuraikan bahwa merek adalah tanda yang ditampilkan secara grafis berupa gambar, logo, nama, kata, huruf, angka, susunan warna, dalam bentuk 2 (dua) dimensi dan/atau 3 (tiga) dimensi, suara, hologram atau kombinasi dari 2 (dua) atau lebih unsur tersebut untuk membedakan barang dan/ jasa yang diproduksi oleh orang atau badan hukum dalam kegiatan perdagangan barang dan/atau jasa.

Jika dirinci unsur-unsurnya dalam UU No 20 tahun 2016 yang Mengatur tentang Tindak pidana terhadap yang melakukan pemalsuan merek yaitu terdiri dari suatu perbuatan melawan hukum, Adanya perbuatan dengan kesengajaan dan obyek ialah merek yang sama pada pokoknya dengan merek merek terdaftar milik pihak lain. Tindak Pidana merek tersebut diatas dimungkinkan untuk menindak beberapa produsen melakukan jalan pintas dengan menjalankan perilaku bisnis curang yaitu dengan melakukan pemalsuan dan Peniruan merek dari barang atau jasa tertentu.Pemalsuan dan Peniruan merek yang

1 Rahmi Jened. Hukum Merek (TradeMark Law) Dalam Era Global dan Integrasi Ekonomi. (jakarta: Ghalia Indonesia, 2015) hlm. 3 
dilakukan oleh beberapa produsen merugikan konsumen tetapi juga merugikan si pemilik merek yang sebenarnya.

Sebagai contoh adalah kasus Probo Subeno Bin Selamet seorang petani yang telah terbukti secara sah dengan melakukan tindak pidanadengan tanpa hak menggunakan merek yang sama pada keseluruhannya dengan merek terdaftar milik pihak lain untuk barang dan/atau jasa sejenis yang diproduksi dan/atau diperdagangkan dalam Putusan No.87/Pid.Sus/2019/PN.Pti.

Adapun dengan cara yaitu membeli garam dari UD. MM dengan merek "Abang Ndut" dan melakukan pengemasan ulang sebanyak 200 ratus (Dua Ratus) pack dan mengganti merek garam terebut menjadi "Ndang Ndut" (menyerupai atau meniru tanda/logo yang terdapat dalam kemasan garam merek "Ndang Ndut"asli) lalu dengan menempeli dengan hologram palsu. Dan hal tersebut dibenarkan dari hasil Pemeriksaan Laboratoris Kriminalistik Nomor: 324/DCF/2019 tanggal 08 Februari 2019, dari Pusat Laboratorium Forensik Bareskrim Polri Laboratorium Forensik Cabang Semarang, yang ditandatangani oleh Budi Santoso, S.Si,M.Si, Dwi Sulistiyono, ST.MT, DedeSetiyarto H, ST, dan Esti Lestari,S.Si dengan diketahui oleh Nursamran Subandi, M.Si, selaku Kepala Laboratorium Forensik Cabang Semarang bahwa si pelaku Probo Subeno Bin Selamet seorang petani telah melanggar yang tertuang di dalam pasal 100 ayat (1) Undang-undang No 15 Tahun 2001 "Tentang Merek" Jo. Undang-undang No 20 Tahun 2016 "Tentang Merek dan Indikasi Geografis".

Terhadap pelaku tindak pidana pelanggaran terhadap merek, pidana yang dapat dijatuhkan berupa pidana penjarapaling lama 5 (lima) tahun dan/atau pidana denda paling banyak Rp2.000.000.000,00 (dua miliar rupiah). Berdasarkan uraian diatas, maka dapat dirumuskan permasalahan yang akan dibahas yaitu :

1. Bagaimanakah Pertanggungjawaban Pidana pelaku tindak pidana melakukan pemalsuan merek dalam Putusan No 87/Pid.sus/2019/Pn.Pti?

2. Bagaimanakah dasar pertimbangan hakim dalam menjatuhkan hukuman kepada pelaku tindak pidana yang melakukan pemalsuan merek dalam Putusan No 87/Pid.sus/2019/Pn.Pti?

\section{Tinjauan Pustaka}

Pemidanaan diartikan sebagai tahap penetapan sanksi dan juga tahap pemberian sanksi dalam hukum pidana. Kata "pidana" pada umumnya diartikan sebagai hukum, sedangkan "pemidanaan" diartikan sebagai penghukuman. ${ }^{3}$ Pemidanaan pada hakikatnya adalah suatu kerugian berupa penderitaan yang sengaja diberikan oleh negara terhadap individu yang melakukan pelanggaran terhadap hukum. Kendatipun demikian, pemidanaan juga adalah suatu pendidikan moral terhadap pelaku yang telah melakukan kejahatan dengan maksud agar tidak lagi mengulangi perbuatannya ${ }^{4}$. Wesley Cragg menyatakan bahwa ada empat hal terkait pemidanaan dalam masyarakat modern.

1. Pemidanan adalah sesuatu yang dapat dimengerti dan tidak dapat dihindari dalam masyarakat modern;

2. Pelaksanaan pemidanaan adalah refleksi sistem peradilan pidana yang berevolusi dan jenis-jenis pidana yang dapat dijatuhkan tidak terlepas dari tipe dan karakter perbuatan pidana yang dilakukan.

\footnotetext{
${ }^{2}$ Undang-undang No 20 Tahun 2016 tentang merek dan Indikasi Geografis

${ }^{3}$ Leden Marpaung. Asas-Teori-Praktik Hukum Pidana. (Jakarta: Sinar Grafika,2005) hlm 2

${ }^{4}$ Eddy O.S. Hiariej. Prinsip-prinsip Hukum Pidana Edisi Revisi. (Yogyakarta: Cahaya Atma Pustaka,2015) hlm 451

${ }^{5}$ Ibid. hlm 451-452
} 
3. Pelaksanaan pidana harus mengalami reformasi yang signifikan dengn merujuk pada pelaksanaan pidana di Eropa Barat dan Amerika Utara. Sejumlah pemidanaan yang digunakan harus menyediakan kriteria unuk mengevaluasi apakah pelaksanaan pidana tersebut sudah sesuai dengan tujuan dari pemidanaan itu sendiri. ${ }^{6}$

Pernyataan di atas, terlihat bahwa pemidanaan itu sama sekali bukan dimaksudkan sebagai upaya balas dendam melainkan sebagai upaya pembinaan bagi seorang pelaku kejahatan sekaligus sebagai upaya preventif terhadap terjadinya kejahatan serupa.

Menurut Wirjono Prodjodikoro, tujuan pemidanaan yaitu: ${ }^{7}$

1) Untuk menakut-nakuti orang jangan sampai melakukan kejahatan baiksecara menakut-nakuti orang banyak (generals preventif) maupun menakut-nakuti orang tertentu yang sudah melakukan kejahatan agar dikemudian hari tidak melakukan kejahatan lagi (speciale preventif), atau

2) Untuk mendidik atau memperbaiki orang-orang yang melakukan kejahatan agar menjadi orang-orang yang baik tabiatnya sehingga bermanfaat bagi masyarakat.

Berdasarkan yang dikemukakan oleh Wirjono Prodjodikoro diatas tujuan pemidanaan diharapkan dapat menjadi sarana perlindungan masyarakat, rehabilitasi dan resosialisasi, pemenuhan pandangan hukum adat, serta aspek psikologi untuk menghilangkan rasa bersalah bagi yang bersangkutan. Tindak pidana adalah kelakuan manusia yang dirumuskan dalam undang-undang, melawan hukum, yang patut dipidana dan dilakukan dengan kesalahan. Orang yang melakukan perbuatan pidana akan mempertanggung jawabkan perbuatan tersebut dengan pidana apabila dia mempunyai kesalahan, seseorang mempunyai kesalahan apabila pada waktu melakukan perbuatan dilihat dari segi masyarakat menunjukkan pada normatif mengenai kesalahan yang telah dilakukan orang tersebut. ${ }^{8}$

Tindak pidana merupakan suatu pengertian dasar dalam hukum pidana. Oleh karena itu memahami pengertian tindak pidana adalah penting sekali. Tindak pidana adalah suatu pengertian yuridis, lain halnya dengan istilah kejahatan (crime) yang bisa diartikan secara yuridis ataupun secara kriminologis. Mengenai pengertian tindak pidana tidak ada kesatuan pendapat diantara para sarjana. Pemalsuan adalah proses pembuatan, beradaptasi, meniru atau benda, statistik, atau dokumen-dokumen (lihat dokumen palsu), dengan maksud untuk menipu. Kejahatan yang serupa dengan penipuan adalah kejahatan memperdaya yang lain, termasuk melalui penggunaan benda yang diperoleh melalui pemalsuan.

Berangkat dari pengertian tersebut, pemalsuan di dunia bisnis mempunyai tujuan untuk mendapatkan keuntungan tanpa melihat apakah tindakan tersebut melanggar hak orang lain atau tidak.Karena pemalsuan mendapatkan keuntungan dari tindakannya dan orang lain menjadi korban yang dirugikan haknya, maka hal tersebut merupakan larangan.

Pemalsuan berasal dari kata palsu yang berarti "tidak tulen, tidak sah, tiruan, gadungan, sedangkan pemalsuan masih dari sumber yang sama diartikan sebagai proses, cara, perbuatan memalsu". ${ }^{9}$ alsu menandakan suatu barang tidakasli, sedangkan

\footnotetext{
${ }^{6}$ Ibid. hlm 451-452

${ }^{7}$ Wirjono Prodjodikoro. Hukum Acara Pidana di Indonesia. (Bandung: Sumur Bandung, 1981).

$\mathrm{h} \operatorname{lm} 16$

${ }^{8}$ Andi Hamzah. Bunga Rapai Hukum Pidana dan Acara Pidana. (Jakarta: Ghalia Indonesia, 2001). $\operatorname{hlm} 40$

${ }^{9}$ Departemen Pendidikan Nasional. Kamus Besar Bahasa Indonesia. (Jakarta: PN. Balai Pustaka, 2008). hlm 817.
} 
pemalsuan adalah proses pembuatan sesuatu barang yang palsu. Sehingga dengan demikian dari kata pemalsuan ada terdapat pelaku, ada barangyang dipalsukan dan ada tujuan pemalsuan. ${ }^{10}$ Perbuatan pemalsuan dapat digolongkan pertama-tama dalam kelompok kejahatan "penipuan", tetapi tidak semua perbuatan penipuan adalah pemalsuan.Perbuatan pemalsuan tergolong kelompok kejahatan penipuan, apabila seseorang memberikan gambaran tentang sesuatu keadaan atas sesuatu barang (surat) seakan-akan asli atau kebenaran tersebut dimilikinya. Karena gambaran ini orang lain terpedaya dan mempercayai bahwa keadaan yang digambarkan atas barang/surat tersebut itu adalah benar atau asli.

Pengertian merek dirumuskan dalam Pasal 1 angka 1 Undang Undang No 20 tahun 2016 tentang merek, yaitu merek adalah tanda yang berupa gambar, nama, kata, hurufhuruf, angka-angka, susunan warna, atau kombinasi dari unsure-unsur tersebut yang memiliki daya pembeda dan digunakan dalam kegiatan perdagangan barang atau jasa. Merek merupakan tanda pengenal dalam kegiatan perdagangan barang atau jasa yang sejenis dan sekaligus merupakan jaminan mutunya bila dibandingkan dengan produk barang atau jasa yang diproduksi pihak lain. Pasal 1 Angka 5 UU No 20 Tahun 2016 Tentang Merek menyatakan bahwa hak atas merek adalah hak eksklusif yang diberikan oleh negara kepada pemilik merek yang terdaftar dalam daftar umum merek untuk jangka waktu tertentu dengan menggunakan sendiri merek tersebut atau memberikan izin kepada pihak lain untuk menggunakannya.

Menurut Muhamad Djumhana dan R.Djubaedillah seperti disitir oleh Adami Chazawi, merek digunakan untuk membedakan barang atau produksi suatu perusahaan dengan barang atau jasa produksi perusahaan lain yang sejenis. Dengan demikian merek adalah tanda pengenal asal barang dan jasa, sekaligus mempunyai fungsi menghubungkan barang dan jasa yang bersangkutan dengan produsennya. Oleh karena itu menggambarkan jaminan kepribadian (individuality) dan reputasi barang dan jasa hasil usahanya sewaktu diperdagangkan. Dalam Pasal 2 Undang Undang No 20 Tahun 2016 Tentang Merek diatur bahwa merek dibedakan menjadi 2 macam, yakni merek dagang dan merek jasa. Merek dagang adalah merek yang digunakan pada barang yang diperdagangkan oleh seseorang atau beberapa orang secara bersama-sama atau badan hukum untuk membedakan dengan barang-barang sejenis lainnya (Pasal 1 angka 2 UU No 20 tahun 2016).

Sedangkan merek jasa adalah merek yang digunakan pada jasa yang diperdagangkan oleh seseorang atau beberapa orang secara bersama-sama atau badan hukum untuk membedakan dengan jasa-jasa sejenis lainnya (Pasal 1 angka 3 UU No. 20 Tahun 2016). Selain itu dalam UU Merek tersebut diatur pula mengenai merek kolektif, yaitu merek dagang atau merek jasa yang digunakan secara bersama-sama (kolektif) oleh beberapa orang atau badan hukum dalam perdagangan. Sebuah merek dapat disebut sebagai merek apabila memenuhi syarat mutlak berupaadanya daya pembeda yang cukup (capable of distinguishing) yakni tanda yang dipakai mempunyai kekuatan untuk membedakan barang atau jasa yang diproduksi suatu perusahaan dari perusahaan lainnya. Untuk mempunyai daya pembeda ini, merek harus dapat memberikan penentuan (individualisering) pada barang atau jasa yang bersangkutan.

\section{Metode}

Jenis penelitian hukum ini termasuk penelitian yuridis normatif yaitu penelitian yang berdasarkan pada bahan kepustakaan yang ada. Penelitian ini dengan pendekatan

\footnotetext{
${ }^{10}$ Ibid.
} 
studi kasus yang meliputi ketentuan perundang-undangan dan putusan pengadilan serta literatur-literatur yang berhubungan dengan pokok bahasan. Bahan hukum yang dilakukan dalam penulisan penelitian ini adalah dengan cara kualitatif, yaitu analisis terhadap isi putusan Pengadilan Negeri Bekasi No.196/Pid.Sus/2019/PN Bks. Tentang dasar pertimbangan hakim menjatuhkan pidana kepada pelaku yang menyebarkan berita bohong atau Hoax, kemudian dilakukan pembahasan dan penafsiran yang ada pada akhirnya dapat ditarik kesimpulan tentang penjatuhan hukuman oleh hakim itu tepat terhadap terdakwa

\section{Pembahasan Dan Hasil}

Didalam Putusan Nomor 87/Pid.Sus/2019/PN.Pti di sebutkan bahwa terdakwa terbukti secara sah dan meyakinkan bersalah melakukan tindak pidana Pemalsuan Merek dengan menyerupai atau meniru tanda/logo yang terdapat tanda/logo merek "Ndang Ndut" Asli lalu ditempeli hologram palsu (alternatif kedua dalam dakwaan), berdasarkan kronologis yang penulis baca, terdakwa benar melakukan perbuatan berupa perbuatan mengirimkan dan memperdagangkan kepada saksi Tarmuji Bin SARNO dan PURNOMO Bin SARNO, dimana barang tersebut berasal dari gudang milik si terdakwa .

Pidana pokok yang dijatuhkan oleh majelis hakim terhadap terdakwa berupa pidana penjara selama 3 (tiga) bulan dan denda sebesar Rp 1.000.000,- (satu juta rupiah), dan dalam pasal 100 ayat (1) UU Nomor 20 tahun 2016 pidana pokok maksimal selama 5 (lima tahun) lamanya dan denda Rp.2.000.000.000,-(dua milyar rupiah). Dalam hal ini penulis kurang setuju karena perbuatan yang dilakukan oleh terdakwa merupakan perbuatan yang cukup berat, dari satu sisi perbuatan telah merugikan pemilik dari UD. KALIAN garam "Ndang-Ndut" hal ini tampak dari terdakwamenjadi salah satu jalan pintas untuk mendapatkan keuntungan yang lebih besar tanpa harusmembayar pajak serta melumpuhkan para kompetitornya di dunia perdagangan.

Berdasarkan hal tersebut penulis berpendapat bahwa perbuatan yang dilakukan oleh terdakwa seharusnya dikaitkan dengan jenis tindak pidana berupa Concursus atau perbarengan. Tindak pidana yang dilakukan oleh terdakwa yang memiliki predicate crime (tindak pidana asal) yaitu tindak pidana pemalsuan maka pemidanaan dari perbuatan ini menyangkut terhadap tindak pidana perbarengan (concursus) yang diatur dalam Kitab Undang-undang Hukum Pidana pada Pasal 63 yang disebut dengan Concursus idealis dan Pasal 65 yang disebut concursus realis. Sebagaimana dalam pasal 63 ayat (1) di sebutkan bahwa: Jika suatu perbuatan masuk dalam lebih dari satu aturan pidana, maka yang dikenakan hanya salah satu di antara aturan-aturan itu, jika berbeda-beda yang dikenakan yang memuat ancaman pidana pokok yang paling berat", pada Pasal 65 ayat (1) disebutkan bahwa:"Dalam hal perbarengan beberapa perbuatan yang harus dipandang sebagai perbuatan yang berdiri sendiri sehingga merupakan beberapa kejahatan, yang diancam dengan pidana pokok yang sejenis, maka dijatuhkan hanya satu pidana".

Berdasarkan pasal tersebut, seharusnya majelis hakim mengaitkan perbuatan terdakwa dengan Perbarengan (concursus) yang sesuai dengan pasal 65 KUHP yaitu concursus realis karena adanya perbuatan yang berdiri sendiri dan digabungkan menjadi beberapa kejahatan yaitu seperti pada dakwaan penuntut umum berupa dakwaan alternatif, dakwaan Primair Pasal 100 ayat (1), atau subsidair Pasal 100 ayat (2) UU Nomor 20 Tahun 2016 tentang Merek dan Indikasi Geografis, yaitu perbuatan yang didasari dengan hasil yang bersumber dari tindak pidana pemalsuan merek dan dikenakan pidana pokok yang sama berupa pidana penjara, maka di jatuhi pidana pokok terberat oleh majelis hakim yaitu pidana pokok yang bersumber dari pasal 100 ayat (1) UU No 20 tahun 2016 tentang Merek dan Indikasi Geografis. 


\section{PATIK : JURNAL HUKUM Vol : 09 No. 2, Agustus 2020, Hal 70 - 78}

Oleh Karena itu penulis kurang setuju dalam putusan yang diberikan oleh majelis hakim terhadap terdakwa.Dalam hal pertanggungjawaban pidana, seorang yang dapat mempertanggungjawabkan perbuatan yang dilakukannya haruslah mampu bertanggung jawab, memiliki kesalahan dan tidak adanya alasan pemaaf. Oleh karena itu, terdakwa Probo Subeno Bin Selamet mampu bertanggungjawab, dan pada umumnya yang bertanggung jawab atas perbuatan pidana adalah orang yang disangka telah melakukan perbuatan itu atau dapat dikatakan seeseorang bertanggung jawab atas perbuatannya sendiri.

Dalam hal perbuatan yang telah dilakukan merupakan perbuatan tindak pidana pemalsuan Merek. Atas perbuatan yang dilakukan oleh terdakwa tidak ditemukan alasan pemaaf mengingat terdakwa tidak tergolong dalam Pasal 44 KUHP yang berisi bahwa "Tiada dapat dipidana barangsiapa mengerjakan suatu perbuatan yang tidak dapat dipertanggungjawabkan kepadanya, sebab kurang sempurna akalnya atau sakit berubah akal mampu bertanggungjawab" dan tidak dapatnya dihapuskan pidana yang diberikan, dalam artian terdakwa jiwanya dalam keadaan normal dan sehat sehingga mampu untuk memepertanggungjawabkan perbuatannya.

Adapun yang menjadi dasar pertimbangan hakim dalam menjatuhkan hukuman kepada Terdakwa didasarkan pada fakta-fakta persidangan yang ditemukan dalam proses penyidikan sampai dengan proses persidangan yang di dalamnya terdapat dasar pertimbangan hakim yang bersifat yuridis dan non yuridis dari latar belakang si terdakwa keadaan jiwa terdakwa, dampak dariperbuatan terdakwa dan agama terdakwa. Selain dari pada itu, hakim juga mempertimbangkan unsur-unsur tindak pidana yang diduga di lakukan oleh terdakwa Probo Subeno Bin Slamet, yaitu:

Ad. 1. Unsur Setiap orang

Dalam pasal 1 angka (19) UU No 20 tahun 2016 tentang Merek dan Indikasi Geografis bahwa yang termasuk kedalam setiap orang adalah orang perseorangan atau Korporasi. Dalam unsur setiap orang ini adalah orang perseorangan yang merupakan terdakwa PROBO SUBENO Bin SLAMET dan merupakan subjek hukum yang dapat mempertanggungjawabkan perbuatannya.Terdakwa dan selama persidangan Majelis Hakim tidak melihat adanya kekeliruan orang (error in persona) dengan demikian unsur telah terpenuhi.

Ad. 2. Unsur tanpa hak adalah tanpa atau melebihi kewenangan, atau tidak berdasarkan hukum, alasan, perintah pengadilan, pembenaran, atau prinsip-prinsip hukum yang relevan.

Oleh karena adanya menyerupai atau meniru tanda/logo yang dilakukan oleh si terdakwa dengan membeli garam yang aslinya merek "Abang Gendut" UD. MM. Gemilang yang beralamat di Desa Margomulyo Kecamatan Juwana Kabupaten Pati seharga Rp. 10.000,- (sepuluh ribu rupiah) per pack, selanjutnya garam cetak tersebut dibawa ke gudang milik terdakwa di Desa Mintomulyo Rt.08 Rw.03 Kecamatan Juwana Kabupaten Pati dan dibuka bungkus/kemasannya untuk kemudian dipindah atau dikemas ulang ke dalam bungkus/kemasan plastik yang terdapat tanda/logo merek "Ndang Ndut" palsu. Adapun terdakwa memperoleh bungkus/kemasan plastik yang terdapat tanda/logo merek "Ndang Ndut" palsu dan hologram palsu tersebut dengan cara memesan dari tempat sablon milik saudara Endol. setelah garam cetak merek "Abang Gendut" dikemas ulang ke dalam kemasan merek "Ndang Ndut" yang palsu kemudian garam tersebut dibeli oleh saksi Tarmuji bin Sarno dan saksi Purnomo bin Sarno dengan harga Rp. 12.500,- (dua belas ribu lima ratus rupiah) dan diangkut menggunakan 1 (satu) unit Truk Nomor Polisi : K-1351-RH dengan tujuan untuk dijual kembali di wilayah Solo. Sesuai dengan keterangan saksi, alat bukti, barang bukti dan keterangan terdakwa, maka majelis hakim menyatakan 
bahwa unsur ini telah terpenuhi dalam diri terdakwa.Berdasarkan dasar pertimbangan hakim selama proses penyidikan hingga sampai di ruang persidangan, hakim menjatuhkan suatu hukuman yaitu dengan menjadikan dasar pertimbangan hakim tersebut menjadi dasar pertimbangan hakim dalam menjatuhkan hukuman terhadap pelaku tindak pidana Pemalsuan Merek.

Ad.3 Menggunakan Merek yang sama pada keseluruhannya dengan Merek terdaftar milik pihak lain untuk barang dan/atau jasa sejenis yang diproduksi dan/atau diperdagangkan sebagaimana dimaksud dalam pasal 100 ayat (1).

Menimbang, bahwa Terdakwa menjual garam cetak / garam bata merek "NDANG NDUT" palsu kepada saksi Purnomo dan saksi Tarmuji dengan harga Rp12.500,00 (dua belas ribu lima ratus rupiah) per pak sehingga setiap penjualan 1 (satu) pak merek garam "NDANG NDUT" palsu tersebut, Terdakwa mendapat keuntungan sebanyak Rp1.000,00 (seribu rupiah) dan bahwa saksi Purnomo dan Saksi Tarmuji sudah beberapa kali membeli garam cetak/garam bata merek "NDANG NDUT" palsu dari Terdakwa sehingga Terdakwa telah memperdagangkan barang sejenis dengan barang yang diperdagangkan oleh UD. KALIAN dengan merek yang sama, yaitu garam cetak / garam bata merek "NDANG NDUT";

Menurut penulis sependapat dengan dasar pertimbangan hakim telah memenuhi rasa keadilan yang substantif yaitu terhadap norma-norma yang berkembang di masyarakat, menurut penulis juga terhadap putusan ini terpenuhinya tujuan pemidanaan memberi rasa jera, walaupun untuk memperbaiki diri si pelaku belum adanya dari dalam diri terdakwa namun hukuman yang dijatuhkan oleh hakim telah setimpal sesuai perbuatan terdakwa.

\section{Kesimpulan Dan Saran}

Pertanggungjawaban pelaku tindak pidana pemalsuan merek sebagaimana dalam pasal 102 UU No 20 tahun 2016 tentang Merek dan Indikasi Geografis adalah setiap orang perseorangan atau badan hukum. Dalam analisis yang dilakukan oleh penulis pertanggungjawaban dalam tindak pidana pemalsuan merek dalam Putusan Nomor 87/Pid.sus/2019/PN.Pti adalah orang perseorangan yang mampu bertanggungjawab karena adanya unsur kesalahan dan tidak adanya alasan pemaaf. Seorang yang dapat dimintakan pertanggungjawabannya adalah orang yang mampu bertanggungjawab, atau dapat dikatakan bahwa orang tersebut jiwanya normal dan sehat tanpa adanya kekurangan dalam bertanggungjawab sebagaimana diatur dalam Pasal 44 Kitab Undang-Undang Hukum Pidana (KUHP)dan benar melakukan suatu kesalahan berupa perbuatan tindak pidana pemalsuan merek dimana pelaku telah mengetahui dan menduga dari perbuatan yang dilakukannya sehingga dapat diberikan hukuman sesuai dengan perbuatannya yang memenuhi unsur tindak pidana dalam dakwaan yang diberikan oleh penuntut umum kepada terdakwa dan terbukti benar dan bersalah. Namun tidak ditemukan alasan pemaaf karena terdakwa mampu mempertanggungjawabkan perbuatannya.

Dasar pertimbangan hakim dalam menjatuhkan hukuman kepada pelaku tindak pidana pemalsuan merek adalah dengan mempertimbangkan Dasar pertimbangan Hakim yang terungkap di dalam persidangan dan harus memiliki pertimbangan yang kuat dalam menjatuhkan hukuman yang dapat memberikan efek jera terhadap terdakwa. Adapun yang menjadi dasar pertimbangan hakim terdiri dari dasar pertimbangan yuridis dan non yuridis. Pertimbangan hakim yang bersifat yuridis adalah alat bukti yang sah berupa keterangan saksi, keterangan ahli, alat bukti surat dan keterangan terdakwa yang terungkap di persidangan. Sedangkan dasar pertimbangan hakim non yuridis adalah hal-hal yang memberatkan dan meringankan terdakwa yang didasarkan pada penilaian objektif dari hakim yang memeriksa dan mengadili perkara tersebut yaitu latar belakang terpidana. Misalnya pertimbangan kepada pelaku tindak pidana pemalsuan merek yang 


\section{PATIK : JURNAL HUKUM Vol : 09 No. 2, Agustus 2020, Hal 70 - 78}

mengakibatkan kerugian terhadap pemilik dari pemegang merek yang asli dalam kasus yang penulis analisis.

Menurut penulis, dalam mengatasi dan melakukan pencegahan terhadap tindak pidana pemalsuan Merek, Penegak hukum di harapkan mampu memberantas dan mengatasi permasalahan tindak pidana pemalsuan merek khususnya dalam tindakan perbuatan passing off, agar terciptanya suatu keamanan dan kestabilan dalam sistem perekonomian dan juga perdagangan. Maka dari itu hakim harus memberikan hukuman yang maksimal agar dapat memberikan efek jera dan mengurangi terjadinya tindak pidana pemalsuan merek yang merupakan salah satu jenis tindak pidana yang masuk kedalam kategori kejahatan luar biasa yang dapat merugikan sistem perekonomian Negara.

\section{DAFTAR PUSTAKA}

\section{Buku}

Ali. Mahrus. Asas-Asas Hukum Pidana Korporasi. Jakarta: Grafindo Persada, 2011.

Ali. Mahrus. Dasar-Dasar Hukum Pidana. Jakarta: Sinar Grafika, 2011.

Armia. Tgk Siddiq. Perkembangan Pemikiran Dalam Ilmu Hukum. Jakarta: Pradnya Paramita, 2003.

Chazawi. Adami. Tindak Pidana Informasi \& Transaksi Elektronik. Malang: Media Nusa Creative, 2015.

Chazawi. Adami. Hukum Pidana Positif Penghinaan. Malang: Media Nusa Creative, 2016. Gunadi. Ismu. Hukum Pidana. Jakarta: Kencana, 2014.

Hamzah. Andi. Delik-Delik Tertentu di dalam KUHP. Jakarta: Sinar Grafika, 2010.

Hiareij. Eddy O.S. Prinsip-Prinsip Hukum Pidana. Yogyakarta: Cahaya Atma Pustaka, 2015.

Ishaq. Hukum Pidana. Jakarta: Rajagrafindo Persada, 2020.

Lamintang. Dasar-Dasar Hukum Pidana di Indonesia. Jakarta: Sinar Grafika, 1997.

Marpaung. Leden. Tindak Pidana Terhadap Kehormatan. Jakarta: Sinar Grafika, 2010.

Marzuki. Peter Mahmud. Penelitian Hukum. Jakarta: Pranata Media Grup, 2015.

Prasetyo. Teguh. Hukum Pidana. Jakarta: Rajagrafindo Persada, 2010.

Renggong. Ruslan. Hukum Pidana Khusus Memahami Delik-Delik Diluar KUHP. Jakarta: Prenamedia Grup, 2016.

Rianto. Agus. Tindak Pidana Pertanggungjawaban Pidana. Surabaya: Kencana, 2016.

Simamora, Janpatar., Tafsir Makna Negara Hukum dalam Perspektif Undang-Undang Dasar Negara Republik Indonesia Tahun 1945, Jurnal Dinamika Hukum FH Universitas Jenderal Soedirman, Vol. 14 No. 3 September 2014.

Siregar. Gomgom. Suatu Analisis Mengenai Tindak Pidana Pencemaran Nama Baik Melalui Media Elektronik. Bandung: Refika Aditama, 2020.

Saleh. Roeslan. Perbuatan Pidana Dan Pertanggungjawaban Pidana. Jakarta: Aksara Baru, 2012.

Wahid. Abdul. Kejahatan Mayantara. Bandung: Refika Aditama, 2010.

Undang-Undang Nomor 19 tahun 2016 tentang Perubahan Atas Undang-Undang Nomor 11 tahun 2008 tentang Informasi dan Transaksi Elektronik. 